\title{
STUDY ON TOOL PERFORMANCES DURING MACHINING PROCESSES UNDER MQL ENVIRONMENT: A REVIEW
}

\author{
VIJAY KUMAR SHARMA ${ }^{1^{*}}$, ANOOP KUMAR SINGH ${ }^{2}$, KAMALJEET SINGH ${ }^{3}$, \\ KASHIDAS CHATTOPADHYAY ${ }^{4} \&$ NISHTHA $^{5}$ \\ ${ }^{1,2,3,4}$ Chitkara University Institute of Engineering and Technology, Chitkara University, Punjab, India \\ ${ }^{5}$ Chitkara School of Health Sciences, Chitkara University, Punjab, India
}

\begin{abstract}
As of now, the main requirement of industries is to produce components of the desired quality, at a high production rate with minimum expenditure. So, industries are adapting machining at high cutting speed and with high feed rates. Highspeed machining increases the temperature in the cutting zone which causes faster tool wear and poor surface finish of the component. To overcome these problems, cutting fluids are used to absorb the heat from the cutting zone during machining. The cutting fluids penetrate the chip-tool interface and quickly form a thin layer there. However, excess use of cutting fluid harmfully affects the environment and health of the worker. Also, the cost associated with cutting fluid increases the total cost of production. Minimum quantity lubrication (MQL) technique can play a crucial function in machining where the use of cutting fluid is necessary. This study presents a review of the comparison of mechanical performances of MQL with other machining environments (Dry machining and Flood cooling) in respect of the tool performances in different machining operations. After review, it is reported that the machining environments have a critical influence on tool wear and surface characteristics. In many studies, the MQL technique has given better results in terms of reduced tool wear than other cooling/lubrication techniques.
\end{abstract}

KEYWORDS: MQL, Dry Machining, Flood Cooling, Tool Wear, Surface Roughness \& Nano-Particles

Received: Jun 06, 2020; Accepted: Jun 26, 2020; Published: Aug 21, 2020; Paper Id.: IJMPERDJUN2020840

\section{INTRODUCTION}

Machining plays a major role in the production of a part using a variety of materials. It is considered as themost flexible manufacturing process in which products of the required dimensions and desired surface finish, are produced by removing excess material [1]. Traditionally, producing a component from hard material is a time-consuming process as multiple steps are needed to convert raw material into the finished product. Machining of hard materials is very expensive as it requires very hard cutting tools and effective cooling/lubrication system. Now a day, Manufacturers are opting for high-speed machining to achieve high productivity at minimum possible production cost and also, without compromising the quality of the finished product. So, it will be essential to optimize the different input parameters of machining process and to obtain the best performances in terms of longer tool life, good surface qualities, high Material removal rates etc [2]. In a machining operation, there are mainly four types of input parameters which are responsible for the output responses of machining, are as follows [3]:

- Machine Parameters: Feed Rate, Depth of Cut, and Cutting Speed

- Machining/Cutting Environments: Cooling/lubrication at cutting zone, the vibration during the process, chip formation and friction in cutting zone. 
- Workpiece: Shape, Workpiece Material and Mechanical Properties.

- Cutting Tool Properties: Tool Geometry, Tool Material, Tool Coating and Tool Shape.

\section{TOOL WEAR}

Tool wear is defined as the loss of material from the cutting edge of the tool. It is mainly because of combine action of mechanical, thermal and chemical factors, on the cutting edge of the tool. Mostly, tool wear is caused by the combination of several wear mechanisms. Different wear mechanisms acting on cutting edge of the tool are abrasion, adhesion, diffusion, fatigue and chemical erosion [4]. Tool life is mainly related to the amount of flank wear. Therefore, flank wear has to be minimized and the width of wear land should not go over the safe limit for a longer duration of machining. The safe limit for most of the single point cutting tools is $0.3-0.5 \mathrm{~mm}$. The normal curve of the wear and cutting time is shown in Figure 1. It represents three zones, a small primary wear zone, a low wear zone and then a failure zone. In the low-wear zone, there is a gradual increase in wear, but in the failure zone, the rate increases rapidly $[5,6]$.

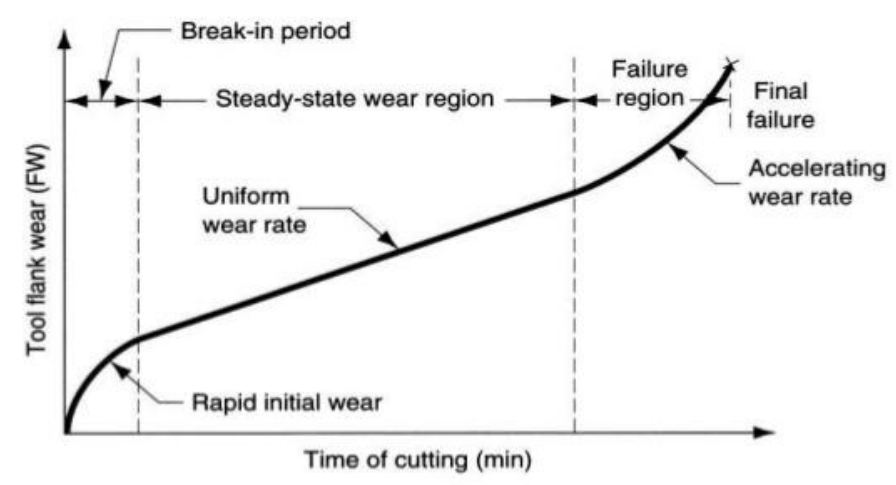

Figure 1: Tool Flank wear as a Function of Cutting Time [6].

Machining costs are a huge part of the overall expenses of the mechanical industry. It includes cutting tool cost, cost of power consumption, labour cost and cutting fluid cost. The cutting tool costs are about $4 \%$ of overall machining cost [7], which may increase to $7.5 \%$ in case of dry cutting [8] and this percentage is even higher in case of machining of hard materials like titanium alloy. To reduce the production cost and for higher productivity, cutting tools with higher tool life are chosen instead of tools having a short tool life [9].

\section{COOLING/LUBRICATION TECHNIQUES IN MACHINING}

Cutting fluid is applied to cutting zoneto lower the temperature at the cutting area. It penetrates the cutting zone to form a layer of lubricant, acts as a coolant and also performs the function of flushing out of the removed materials (chips). The various type of cooling/Lubrication techniques used in machining are as follows:

- Dry machining: Dry machining is done without the application of lubricant to protect the environment and to reduce costs. Air is the only medium of heat removal so heat build-up must be avoided in dry machining. Dry machining is not so effective at high speeds and feed rates and also in the machining of hard materials as high heat is generated at the cutting zone while machining which affects tool performance [10-13].

- Flood cooling: In flood cooling, a large amount of lubricant/coolantis supplied to machining area in the forms a liquid jet by a nozzle which completely inundates the entire cutting zone. It is assumed that a large amount of cutting 
fluid absorb more heat from the cutting zone $[\mathbf{9 , 1 4 ]}$. Water-based lubricants/coolants are mostly used because of their lower cost and functionality of conduction of heat [15].

- Minimum Quantity Lubrication (MQL): In MQL, a little quantity of cutting fluid is combined with pressurized air to form anaerosol which is sprayed to the machining zone by a nozzle. This aerosol having ultra-fine particles can get close to the tool-chip and tool-workpiece interface, therefore lowering the friction and also lowers the temperature of the cutting zone[6]. Cutting fluid evaporates at the cutting zone so there is no need for circulation and disposal of cutting fluid[16]. MQL can be considered as a good cooling option compared to other cooling environments because of high heat dissipation and lubricating capability[17].

\section{ECOLOGICAL AND ECONOMICAL ASPECTS OF COOLING/LUBRICATION TECHNIQUES}

Although the use of cutting fluid is necessary for lots of machining process, excess use of cutting fluid harmfully affects the environment and health of the worker. Many studies have suggested to avoid the use of these fluids[13].Continued contacts of machine operators with cutting fluids may cause skin and respiratory diseases. It was observed that the disposal of cutting fluids also badly affects the environment and human health [8] and improper disposal leads to ground, water or air pollution [14]. Many researchers have done investigation and surveys to find out the effects of metalworking fluid on the human and environment. Schwarz et al. [18]found during their study that machine operators exposed to metalworking/cutting fluids have high possibilities of health problems like respiratory diseases, cancer, allergies, and skin diseases. Suuronen et al [19] examined the data of Finnish Register of Occupational Diseases, to check the occurrence of Occupational Skin Diseases (OSDs) and Allergic Respiratory Diseases (ARDs) in workers of the metal fabrication industry. Prolonged contact with Metalworking fluids was found the main reason for OSDs in workers. ARDs (mostly the asthmas)were caused by metalworking fluids and their vapours along with metal dust. Meza et al. [20]also have done an investigation to check the effects of continued contacts of machine operators with Metalworking fluids. Estimated prevalence ratios (PR) of ARDs symptoms were examined. A higher ratio of asthma, WRA, and dermatitis symptoms were reported in exposed workers than unexposed workers.

Also, the cost of maintaining and disposal of cutting fluids is very high. So, engineers and researchers are forced to find an environment-friendly lubrication/cooling system in machining in the manufacturing industry [21]. For the manufacturing industries, the costs associated with cutting fluids range from 7 to $17 \%$ [8] which is much higher than the tool costs [22]. Lubricant/coolant costs include the cost of setting a Lubricant/coolant delivery system, lubricant purchase and system maintenance cost and waste treatment cost. The costs for cooling is about $16.9 \%$ of the entire production costs as explained by the pie chart shown in figure 2. Considering the costs for tools (4\%), it seems incomprehensible that maximum researcher focuses on to reduce tool cost only[23].So, the need of the time is to consider the cost of cutting fluid along with the cost of the tool while examining economics in machining [7]. 


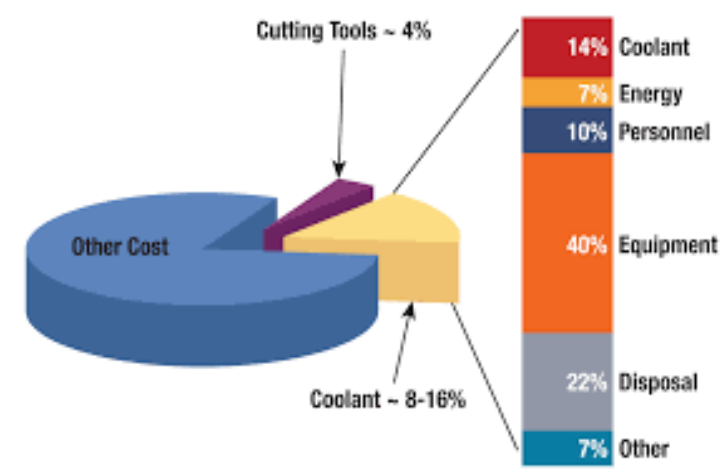

Figure 2: Production Costs for an Engine part [23].

\section{PERFORMANCE OF MQL DURING DIFFERENT MACHINING PROCESSES}

Manufacturing industries looking for higher productivity, forced to do machining at high speeds and feeds. High-speed Machining generates high heat at machining zone resulting high cutting temperature. High cutting zone temperature leads to faster tool wear and poor surface qualities. Many researchers have applied the MQL in turning of various materials to compare the results of MQL with dry machining and conventional flood cooling in terms of tool performance, surface properties and other responses. Dhar et al. [24] applied the MQL in turning of AISI-4340 steel by carbide inserts. A lower cutting area temperature was observed using MQL in comparison with dry machining and conventional flood cutting and the sharpness of tool is maintained for a longer time. Further, it resulted in lower flank wear with an improved surface finish as shown in figure 3.

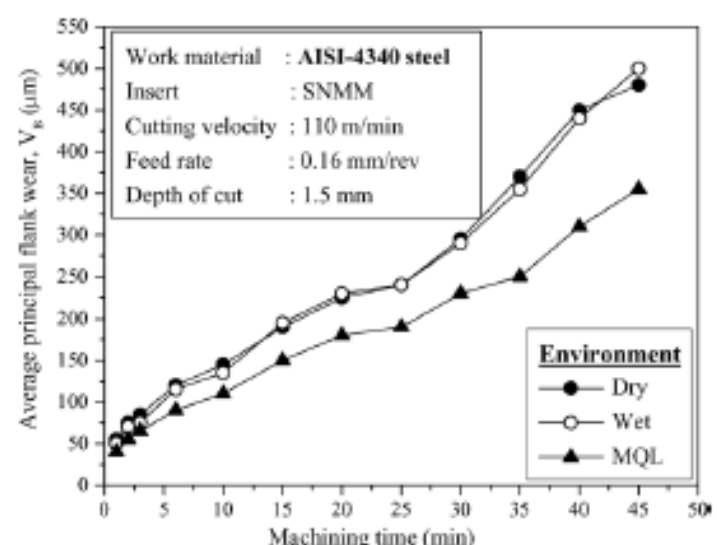

(a)

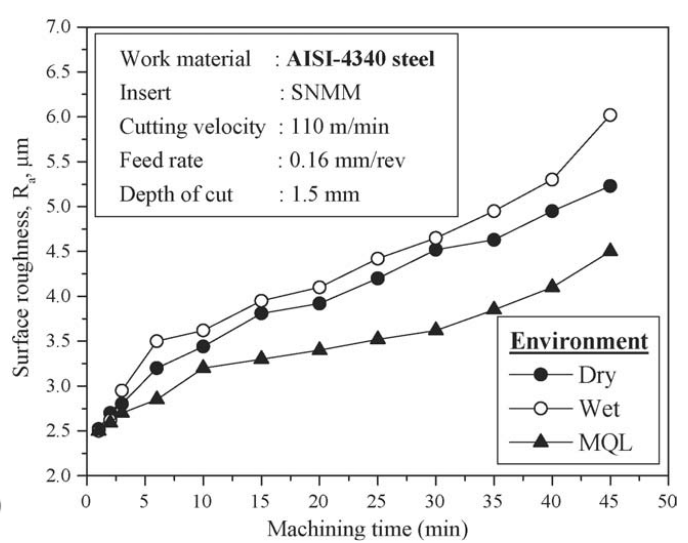

(b)

Figure 3: (a) Flank Wear \& (b) Surface Roughness with Machine Time [24].

Kamata and Obikawa[25] did an experimental investigation of tool life and surface finish during high-speed turning of Inconel-718 using various cooling/lubrication techniques. The study reported that the tool life under MQL conditions was higher than that of wet and dry conditions with improves surface qualities as shown in figure4. 


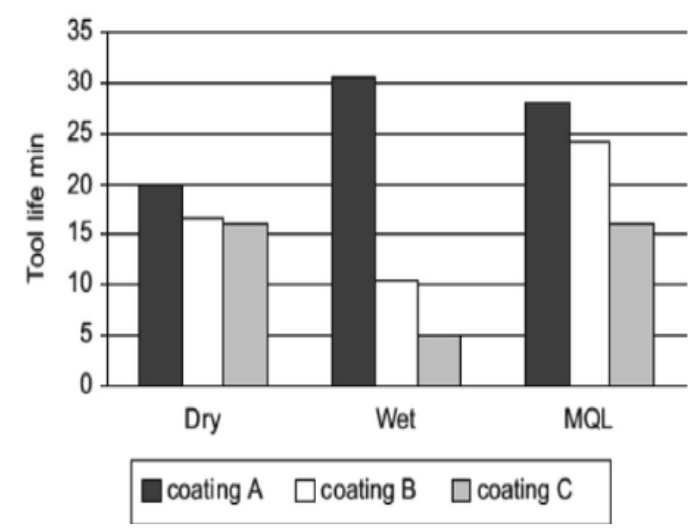

Figure: 4: Tool Lives in Different Machining Environments [25].

Khan et al. [26] also did the turning of alloy steel under dry, MQL and wet environments. A lower machine zone temperature with better tool-chip interaction was reported under MQL. Also, under MQL lesser tool wear with the improved surface finish was found as compared to dry and wet machining. Sainietal. [27] did experiments to check the effects of MQL based turning and dry turning of AISI-4340steel. Using MQL, the reductions of $13.25 \%$ and $5.73 \%$ were reported in the values cutting forces and cutting temperature respectively. Chinchanikarand Choudhury[28] also did hard turning on AISI 340 steel using HiPIMS-coated carbide tools. It was observed that that tool life was improved by $20-25 \%$ using MQL as MQL provide better cooling and lubricating effects. Flank wear was analysed by SEM and was mainly caused by adhesion and abrasion while nose wear and crater wear were caused by diffusion. Turning on AISI D2 steel was carried out by Sharma and Sidhu[29] using tungsten carbide tool inserts and a reduction of 50\% in cutting temperature was reported under near dry machining. Sarıkaya and Güllü[30] did optimization of MQL parameters in turning of Haynes 25 by an uncoated carbide tool. The study has revealed that vegetable-based lubricant with a supply rate of $180 \mathrm{ml} / \mathrm{h}$ gives lesser tool wear and higher surface finish. Rahim et al. [31] compared the efficiency of MQL to dry machining while performing orthogonal cutting of carbon steel AISI 1045 on the lathe using carbide insert as a tool. The analysis reported that MQL significantly lowered the machining temperature and cutting forces as compared to dry cutting. Mia et al. [32] performed the experiments to know the influence of various input parameters on roughness, tool wear and material removal rate (MRR) in MQL-assisted hard turning of AISI 1060 steel by coated cemented carbide tool. Tool wear analysis reported that the wear was mainly caused by adhesion and abrasion.

Experimental investigation during the milling operations under MQL was done by many researchers. Rahman et al. [33] experimentally investigated the effects of MQL on cutting force, surface roughness and chip shape during the end milling of hardened steel using uncoated carbide inserts. Based on the results of investigations, they revealed that the MQL has given better results for tool life with a good surface finish at low speed and low feed rate than flood cooling as Flank wear was minimum at low speed and feed rates. By EDX analysis it was found that MQL gave better lubrication effect. Kishawy et al. [34] inspected the impact of various cooling systems on tool performance during milling of aluminium alloy A-356. From experimental results, it was observed that flank wear is lower in case of MQL as plot showing in figure 5. 


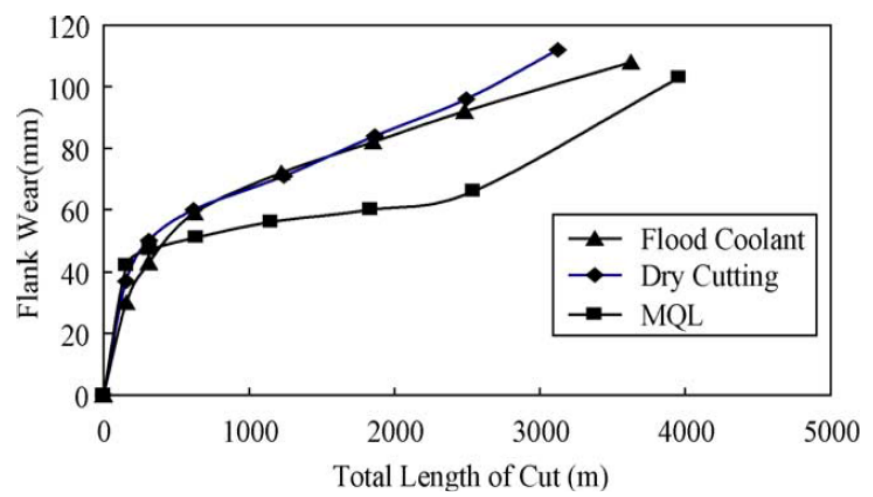

Figure 5: Flank Wear Progress for Uncoated Carbide Inserts [34].

Lacalle et al. [35] also compared the influence of different cooling techniques on tool performance while milling of aluminium alloy. The analysis was done using Computational Fluid Dynamics (CFD) simulations to estimate the penetration of lubricant into the Machining zone. It was observed that flank wear is lower using MQL than emulsion flood cooling. From the analysis, it was also revealed that oil mist with high velocity successfully reached in the inner side of cutting edge which caused adequate cooling and lubrication. Liao et al. [36] did experimental study during high-speed end milling of NAK80 hardened steel using coated carbide tool and the analysis of the effects of various machining environments on tool life was done. It was found that the MQL leads to the significant improvement in tool life due to the formation of the protective metal-oxide layer at the chip-tool interface. Similar formation of a protective oxide layer at the interface using MQL technique was also reported by Liew et al [37] during milling of SS-420 stainless steel. The presence of the protective layer reduced the frictional forces and results in lower abrasive wear of the tool. Kang et al. [38] performed high-speed milling of AISI D2 die steel in various machining environments and performance of coated carbides tools was studied. In flood cooling, the formation of thermal cracks was observed on the flankface which causes cracking and chipping off cutting edge. MQL supply eliminated the effects of thermal damage on the tool which results in better tool performance than flood cooling. Sales et al. [39] evaluated the tool wear experimentally using vegetable oil-based cutting fluid during milling of AISI 4140 steel with TiAlN coated cemented carbide inserts. The flow rate of coolant was chosen between 0 (dry cutting) to $200 \mathrm{ml} / \mathrm{h}$.A significant decrement in tool wear with an increase in coolant flow rate was reported. Liu et al. [40] did experimental investigation during end milling of titanium alloy using TiAlNcoated Kennametal inserts by varying the air pressure, oil quantity and using different nozzle positions. It was found that the up to a certain value, increase in the oil quantity, reducesthe cutting force and cutting temperature. So the minimum quantity of lubricant was determined. The effectiveness of the spraying angle was only found when the viscosity of lubricant was low. Cai. et al. [41] studied the influence of the lubricant supply rate in end milling of titanium alloy using MQL. It was revealed that up to a certain upper limit, increases in lubricant flow rate, decreases the cutting force and tool chipping edge length. This is because higher supply rate resulted in adequate penetration of lubricant in the machining zone. The mechanism tool wear has been changed from diffusion wear to steady wear at higher lubricant supply rate. Similar results of tool wear reduction with the increase in oil flow rate also observed by Yan et al. [42], when an experimental investigation was carried out during milling of forged steel by altering the MQL parameters (nozzle to feed direction, nozzle elevation angle, nozzle-work distance, lubricant supply rate and air pressure). The lubricant reached the cutting zone effectively at high air pressure. The analysis has revealed that the nozzle feed position should be such that the complete oil mist drop enters in cutting zone. Nozzle elevation angle should be selected such that, curly chips and oil mist stream do not obstruct the path of each other during flushing and lubrication 
process. Higher nozzle-work distance, reduce the amount of lubrication, however, the quite short value of nozzle-work distance can increase the possibility of incomplete lubrication. Zhang et al.[43] performed experiments to study the influence of the different cooling/lubricating techniques on tool wear of coated carbide tool in end milling of Inconel 718. The analysis has shown that Minimum Quantity Cooling Lubrication (MCQL) leads to higher tool life and lower cutting forces. Sunet al. [6] also studied the effect of dry machining, flood cooling and MQL on tool life and cutting force during end milling of Titanium alloys using a carbide tool. It was observed that the tool life achieved using MQL was longer than flood cooling and dry machining shown in figure 6as MQL leads to better lubrication and cooling effect.

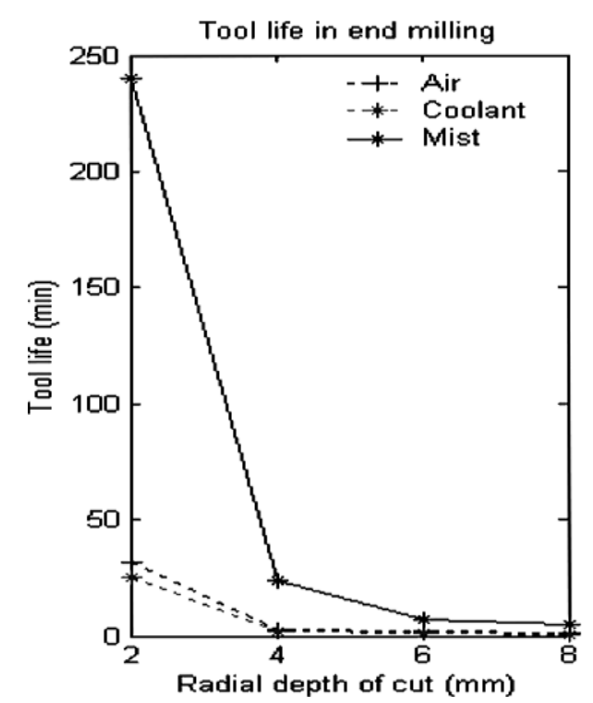

Figure 6: Tool Life Vs Depth of Cut in Different Cooling/Lubrication [6].

Wang et al.[44] investigated the tool wear of the uncoated tool and PVD coated tool during face milling of Inconel 182 by altering the positions of MQL nozzle. It was observed that the proper nozzle position can increase tool life by providing better lubrication efficiency. Reduction in tool wear was also observed by Al Bashir et al. [45] during experimental investigation in milling hardened AISI 4140 steel of hardness 40 HRC in both dry and pulse jet MQL conditions. The comparative analysis shown in figure7 indicates that the use of a pulsed jet MQL applicator reduced the flank wear thus increases the tool life. Most favoured conditions for lower surface roughness were found at the lubricant flow rate of $150 \mathrm{ml} / \mathrm{h}$.

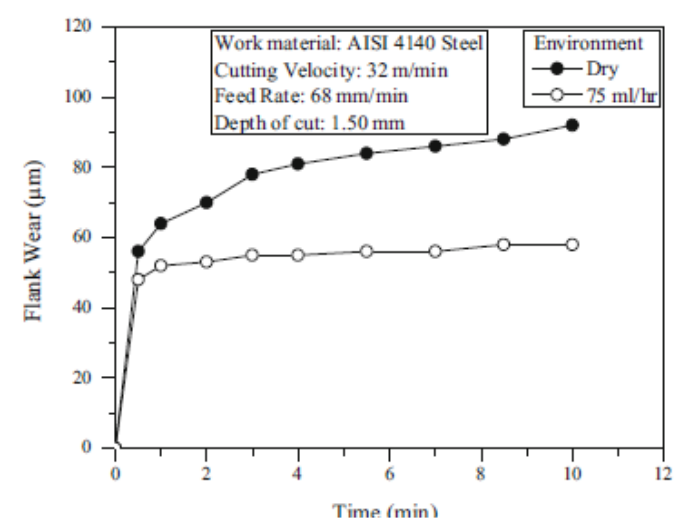

Figure 7: Tool Flank Wear Vs Machining Time [45].

Werda et. al.[46]focused on the position of application of lubricant using the MQL technique in milling of 
$\mathrm{X} 100 \mathrm{CrMoV} 5$ steel alloy. It was found that the application of lubricant to flank face reported $10 \%$ and $28.5 \%$ longer tool life than the application of lubricant to rake face and dry machining respectively. Singh et al. [47] found lesser flank wear using MQL conditions than wet and dry machining when milling of Stainless Steel 304 using Coated Carbide Tool Insert was performed. Better lubrication and penetration was observed in MQL conditions. Similar lubrication and penetration effects observed by Babu et al.[48] during end Milling of AISI 304 steel and a reduction of 70\% in the tool wear of carbide tool was recorded using MQL when compared with flood Lubrication. Singh et al. [49] have performed milling experiments on the difficult-to-cut Inconel 718 super alloy dry, flood, and MQL conditions using AlTiN+TiN PVD-coated inserts. PSO and BFO methods of optimization were used and analysis showed that MQL performed better than dry machining and flood cooling in terms of tool flank wear. At higher speeds, results were even better under MQL conditions.

Heinemann et al. [50] applied the MQL technique in drilling to study the effects of the lubricant supply manner on the tool life of HSS twist drills. It was reported that the lubrication using continuous supply offered higher tool life than the discontinuous supply. Less viscous lubricant offered better penetration in machine zone which also resulted in higher tool life. Meena and Mansori [51] conducted experiments on Au stempered Ductile Iron (ADI) using the TiAlN-coated tungsten carbide tools of diameter $8 \mathrm{~mm}$ and Swiss cut frisco 6122S lubricant as cutting fluid. Results showed that the MQL system leads to higher tool life with a better quality of hole and performance was also comparable to flood cooling. Reduction in the drill wear also observed by the Bhowmick and Alpas [52] while drilling the Cast magnesium alloy (AZ91) using the uncoated HSS drill MQL. The analysis reported that using MQL, the temperature at cutting zone was reduced which results in less drill wear as shown in figure 8.

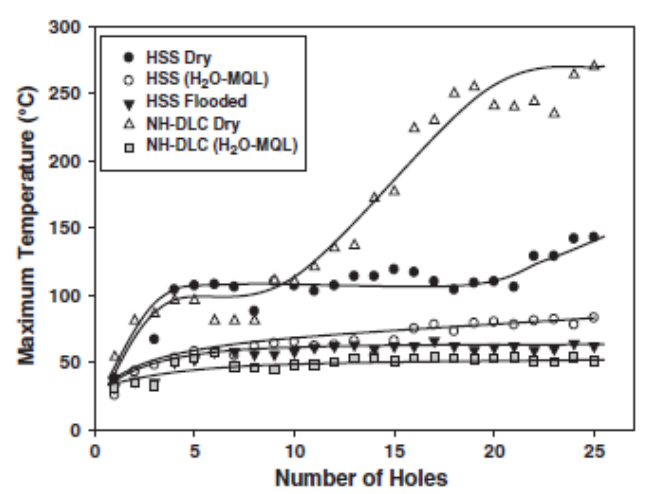

Figure 8: Maximum Temperature Variations for the First 25 Holes During Drilling [52].

Table 1: Summary of the Effects of the MQL Technique on Tool Performances in Different Machining

\begin{tabular}{|l|l|l|l|l|}
\hline \multicolumn{1}{|c|}{ Authors } & \multicolumn{1}{c|}{ Cutting Tool } & \multicolumn{1}{c|}{$\begin{array}{c}\text { Workpiece } \\
\text { Material }\end{array}$} & $\begin{array}{l}\text { Lubrication } \\
\text { Techniques }\end{array}$ & \multicolumn{1}{c|}{ Findings } \\
\hline Dhar et al. [24] & $\begin{array}{l}\text { Uncoated Carbide } \\
\text { Inserts }\end{array}$ & AISI 4340 steel & $\begin{array}{l}\text { MQL, Dry, } \\
\text { Flood }\end{array}$ & $\begin{array}{l}\text { MQL showed lower flank wear with } \\
\text { an improved surface finish }\end{array}$ \\
\hline $\begin{array}{l}\text { Kamata and } \\
\text { Obikawa [25] }\end{array}$ & $\begin{array}{l}\text { Coated Carbide } \\
\text { Tools }\end{array}$ & Inconel 718 & $\begin{array}{l}\text { MQL, Dry, } \\
\text { Flood }\end{array}$ & $\begin{array}{l}\text { tool life under MQL was higher with } \\
\text { good Surface qualities }\end{array}$ \\
\hline Khan et al., [26] & $\begin{array}{l}\text { Uncoated Carbide } \\
\text { Inserts }\end{array}$ & AISI 9310 steel & $\begin{array}{l}\text { MQL, Dry, } \\
\text { Flood }\end{array}$ & $\begin{array}{l}\text { Using MQL lower tool wear with the } \\
\text { improved surface finish was found }\end{array}$ \\
\hline Saini et al., [27] & $\begin{array}{l}\text { Uncoated Carbide } \\
\text { Inserts }\end{array}$ & AISI 4340 steel & MQL, Dry & $\begin{array}{l}\text { The reductions of 13.25\% and 5.73\% } \\
\text { were reported in the values cutting } \\
\text { forces got and cutting temperature } \\
\text { respectively under MQL condition }\end{array}$ \\
\hline
\end{tabular}




\begin{tabular}{|c|c|c|c|c|}
\hline $\begin{array}{l}\text { Chinchanikar } \\
\text { and Choudhury } \\
\text { [28] }\end{array}$ & $\begin{array}{l}\text { Hipims-Coated } \\
\text { Carbide Tools }\end{array}$ & AISI 4340 steel & MQL, Dry & $\begin{array}{l}\text { MQL provide superior } \\
\text { cooling/lubricating effects }\end{array}$ \\
\hline $\begin{array}{l}\text { Sharma and } \\
\text { Sidhu [29] }\end{array}$ & $\begin{array}{l}\text { Tungsten Carbide } \\
\text { Tool }\end{array}$ & AISI D2 steel & MQL, Dry & $\begin{array}{l}\text { Reduction of } 50 \% \text { in cutting } \\
\text { temperature under MQL }\end{array}$ \\
\hline $\begin{array}{l}\text { Sarrkaya and } \\
\text { Gülllü[30] }\end{array}$ & $\begin{array}{l}\text { Uncoated Carbide } \\
\text { Tool }\end{array}$ & Haynes 25 & MQL & $\begin{array}{l}\text { The supply rate of } 180 \mathrm{ml} / \mathrm{h} \text { gives } \\
\text { lesser tool wear and higher surface } \\
\text { finish }\end{array}$ \\
\hline Rahim et al. [31] & $\begin{array}{l}\text { Uncoated Carbide } \\
\text { Inserts }\end{array}$ & AISI 1045 steel & MQL, Dry & $\begin{array}{l}\text { lesser cutting temperature and } \\
\text { cutting forces than dry cutting }\end{array}$ \\
\hline Mia et al. [32] & $\begin{array}{l}\text { Coated Cemented } \\
\text { Carbide Tool }\end{array}$ & AISI 1060 steel & MQL & $\begin{array}{l}\text { Optimization of machining } \\
\text { parameter under MQL }\end{array}$ \\
\hline $\begin{array}{l}\text { Rahman et al. } \\
\text { [33] }\end{array}$ & $\begin{array}{l}\text { Uncoated Carbide } \\
\text { Inserts }\end{array}$ & Hardened steel & $\begin{array}{l}\text { MQL, Dry, } \\
\text { Flood }\end{array}$ & $\begin{array}{l}\text { MQL has given better results for tool } \\
\text { life with a good surface finish }\end{array}$ \\
\hline $\begin{array}{l}\text { Kishawy et al. } \\
\text { [34] }\end{array}$ & $\begin{array}{l}\text { Uncoated and } \\
\text { Diamond Coated } \\
\text { Carbide Inserts } \\
\end{array}$ & $\begin{array}{l}\text { Aluminium alloy } \\
\text { A-356 }\end{array}$ & $\begin{array}{l}\text { MQL, dry, } \\
\text { Flood }\end{array}$ & $\begin{array}{l}\text { Lesser Flank wear under MQL than } \\
\text { other machining environments }\end{array}$ \\
\hline $\begin{array}{l}\text { Lacalle et al. } \\
{[35]}\end{array}$ & $\begin{array}{l}\text { High Speed } \\
\text { Steel }\end{array}$ & $\begin{array}{l}\text { Aluminium alloy } \\
\text { used in the tests is } \\
\text { the 5083-H112 }\end{array}$ & MQL, Flood & Lesser Flank wear under MQL \\
\hline Liao et al. [36] & $\begin{array}{l}\text { Coated Carbide } \\
\text { Tool }\end{array}$ & $\begin{array}{l}\text { NAK80 hardened } \\
\text { steel }\end{array}$ & MQL, Dry & $\begin{array}{l}\text { MQL leads to a significant } \\
\text { improvement in tool life }\end{array}$ \\
\hline Liew et al [37] & $\begin{array}{l}\text { TiAlN/AlCrN } \\
\text { coated } \\
\text { and uncoated } \\
\text { carbide tools }\end{array}$ & $\begin{array}{l}\text { STAVAX } \\
\text { (modified } 420 \\
\text { stainless steel) }\end{array}$ & MQL, Flood & $\begin{array}{l}\text { Performance of MQL was better } \\
\text { because of the high reduction in the } \\
\text { frictional forces }\end{array}$ \\
\hline Kang et al. [38] & $\begin{array}{l}\text { Coated Carbides } \\
\text { Tools }\end{array}$ & $\begin{array}{l}\text { AISI D2 cold- } \\
\text { worked die steel }\end{array}$ & $\begin{array}{l}\text { MQL, Dry, } \\
\text { Flood }\end{array}$ & $\begin{array}{l}\text { Tool performances were found better } \\
\text { under MQL }\end{array}$ \\
\hline Sales et al. [39] & $\begin{array}{l}\text { Tialn Coated } \\
\text { Cemented Carbide } \\
\text { Inserts. }\end{array}$ & AISI 4140 steel & MQL, Dry & $\begin{array}{l}\text { Reduction in tool wear with } \\
\text { increased coolant flow rate with the } \\
\text { improved surface finish }\end{array}$ \\
\hline Liu et al. [40] & $\begin{array}{l}\text { PVD Tialn Coated } \\
\text { Kennametal Inserts }\end{array}$ & Ti-6Al-4V alloy & MQL & $\begin{array}{l}\text { Minimum quantity of lubricant was } \\
\text { determined }\end{array}$ \\
\hline Cai. et al. [41] & $\begin{array}{l}\text { PVD Tialn Coated } \\
\text { Kennametal Inserts }\end{array}$ & Ti-6Al-4V alloy & MQL, Dry & $\begin{array}{l}\text { Increase in lubricant flow rate, } \\
\text { decreased the cutting force, tool } \\
\text { chipping edge length and results in } \\
\text { better surface qualities }\end{array}$ \\
\hline Yan et al. [42], & $\begin{array}{l}\text { Coated Carbide } \\
\text { Inserts }\end{array}$ & Forged steel & $\begin{array}{l}\text { MQL, Dry, } \\
\text { Flood }\end{array}$ & $\begin{array}{l}\text { Values of Optimized MQL } \\
\text { parameters for lower tool wear is } \\
\text { determined }\end{array}$ \\
\hline Zhang et al. [43] & $\begin{array}{l}\text { Tin Coated Carbide } \\
\text { Tool }\end{array}$ & Inconel 718 & Dry, MCQL & $\begin{array}{l}\text { MQCL leads to higher tool life and } \\
\text { reduction of cutting forces }\end{array}$ \\
\hline Sun et al. [6] & Carbide Tool & Ti-6Al-4V alloy & $\begin{array}{l}\text { MQL, Dry, } \\
\text { Flood }\end{array}$ & $\begin{array}{l}\text { Tool life achieved using MQL was } \\
\text { longer than flood cooling and dry } \\
\text { machining }\end{array}$ \\
\hline Wang et al. [44] & $\begin{array}{l}\text { Uncoated And } \\
\text { Tialn/Tin PVD } \\
\text { Coated Carbide } \\
\text { Inserts }\end{array}$ & Inconel 182 & MQL & $\begin{array}{l}\text { Suitable MQL nozzle positioned was } \\
\text { found }\end{array}$ \\
\hline $\begin{array}{l}\text { Al Bashir et al. } \\
\text { [45] }\end{array}$ & Carbide Tool & $\begin{array}{l}\text { Hardened AISI } \\
4140 \text { steel }\end{array}$ & MQL, Dry & $\begin{array}{l}\text { Pulsed jet MQL applicator reduced } \\
\text { the flank wear }\end{array}$ \\
\hline $\begin{array}{l}\text { Werda et. al. } \\
{[46]}\end{array}$ & Carbide Inserts & $\begin{array}{l}\text { X100CrMoV5 steel } \\
\text { alloy }\end{array}$ & MQL & $\begin{array}{l}\text { Application of lubricant to flank face } \\
\text { results in higher tool life }\end{array}$ \\
\hline Singh et al.[47] & $\begin{array}{l}\text { Coated Carbide } \\
\text { Tool Insert }\end{array}$ & Stainless Steel 304 & $\begin{array}{l}\text { MQL, Dry, } \\
\text { Flood }\end{array}$ & $\begin{array}{l}\text { Lesser Flank wear under MQL than } \\
\text { other machining environments }\end{array}$ \\
\hline
\end{tabular}




\begin{tabular}{|l|l|l|l|l|}
\hline Babu et al. [48] & carbide tool & AISI 304 steel & $\begin{array}{l}\text { MQL, Dry, } \\
\text { Flood }\end{array}$ & $\begin{array}{l}\text { A reduction of 70\% in the tool wear } \\
\text { using MQL as compared to flood } \\
\text { Lubrication }\end{array}$ \\
\hline Singh et al. [49] & $\begin{array}{l}\text { Altin+Tin PVD- } \\
\text { Coated Inserts }\end{array}$ & Inconel 718 & $\begin{array}{l}\text { MQL, Dry, } \\
\text { Flood }\end{array}$ & $\begin{array}{l}\text { Lesser Flank wear under MQL than } \\
\text { other machining environments }\end{array}$ \\
\hline $\begin{array}{l}\text { Heinemann et al. } \\
\text { [50] }\end{array}$ & $\begin{array}{l}\text { High-Speed Steel } \\
\text { Twist Drills }\end{array}$ & Carbon steel & MQL & $\begin{array}{l}\text { Continuous application of lubricant } \\
\text { reported higher tool life than the } \\
\text { discontinuous supply. }\end{array}$ \\
\hline $\begin{array}{l}\text { Meena and } \\
\text { Mansori[51] }\end{array}$ & $\begin{array}{l}\text { Tialn-Coated } \\
\text { Tungsten Carbide } \\
\text { Drill }\end{array}$ & $\begin{array}{l}\text { Austempered } \\
\text { Ductile Iron }\end{array}$ & MQL, Flood & $\begin{array}{l}\text { MQL system leads to higher tool life } \\
\text { than flood cooling }\end{array}$ \\
\hline $\begin{array}{l}\text { Bhowmick and } \\
\text { Alpas[52] }\end{array}$ & $\begin{array}{l}\text { Uncoated HSS } \\
\text { Drill }\end{array}$ & Magnesium alloy & $\begin{array}{l}\text { MQL, Dry, } \\
\text { Flood }\end{array}$ & $\begin{array}{l}\text { Cutting zone temperature was } \\
\text { reduced using MQL which results in } \\
\text { lesser drill wear than flood and dry } \\
\text { machining. }\end{array}$ \\
\hline
\end{tabular}

\section{APPLICATION OF NANO-FLUID LUBRICANTS IN MQL: NMQL}

The cooling capabilities of cutting fluid can be increased by adding the nano-particles in the base fluid [53]. Amrita et al. [54]did an experiment alevaluationto check the performance of nano graphite-based MQL during turning of AISI-1040 steel using a cemented carbide tool insert. The Analysis has reported that use of the Nanofluidin MQL results in 54\% reduction in cutting forces, $25 \%$ reduction in cutting temperature, $71 \%$ reduction in tool wear and $30 \%$ reduction in surface roughness in comparison with conventional MQL application. The results for flank wear using different machining environments are shown in figure 9. Nanofluid droplets penetrate effectively the cutting zone which leads to better cooling and lubricating action at interfaces.

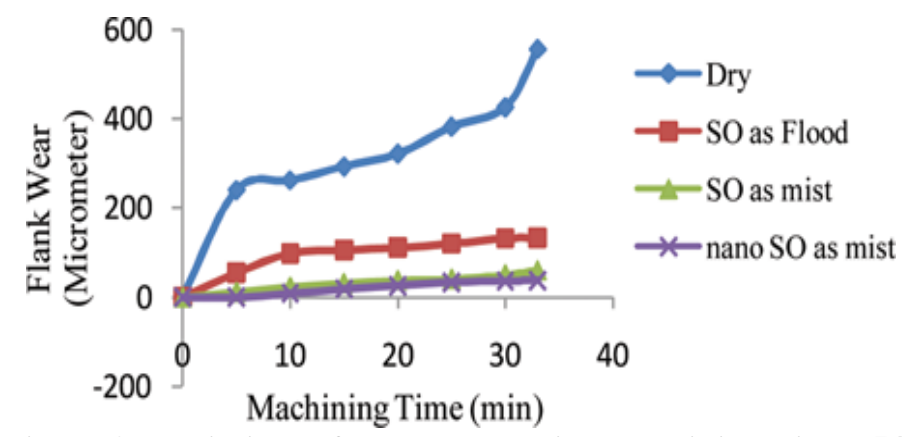

Figure 9: Variations of Flank wear with Machining Time [54].

Thakur et al. [55] have done a comparative analysis of MQL and SiCnanoparticle-based MQL in turning of EN24 Steel using TiAlN CVD coated tungsten carbide insert. The results showed that NMQL gave better results in terms of lower cutting force and cutting temperature and also improve the surface qualities. Yıldırımet al. [56] used NMQL technique by adding hBN nanoparticles in base fluidand comparison of results wasdone with results of pure-MQL and dry cutting in turning of Inconel 625. The best result of tool performances was found using the NMQL technique.T he reduction of 43\% in tool wear was recorded using 0.5 vol\% hBNnano-fluid as shown in figure 10. 


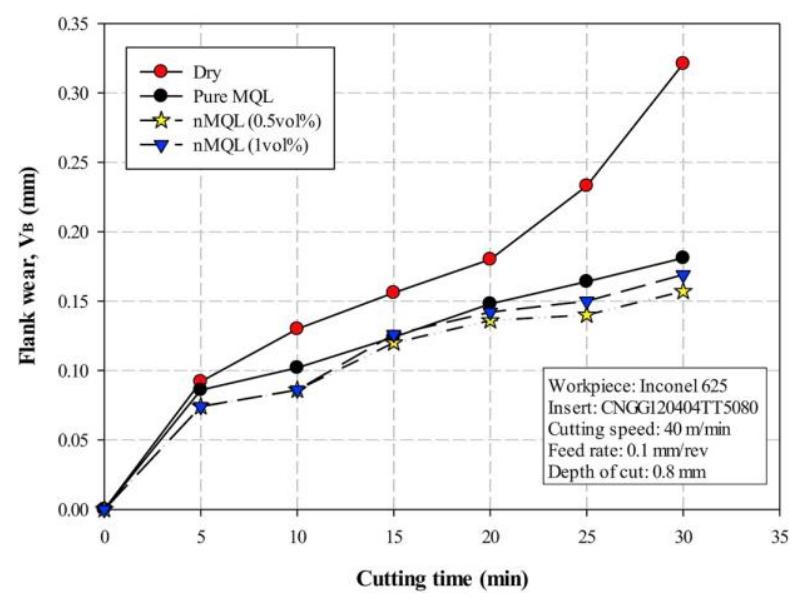

Figure 10: The Relationship between Cutting Time and Flank wear [56].

Sharma et al. [57] investigated the performance of $\mathrm{SiO}_{2}$ nanoparticle-Based cutting fluid in turning of AISI 1040 steel using uncoated cemented carbide insert. Application of $\mathrm{SiO}_{2}$ based-Nano fluid reduced the tool wear by $57 \%$ approximately as compared to dry machining and 34\% approximately when compared to simple MQL system. Park et al. [58] conducted experiments by applying nanographene-enhanced coolant in MQL during ball milling of AISI 1045 steel $203.2 \mathrm{~mm}$ ) using a $25 \mathrm{~mm}$ diameter ball-nose TiAlN coated carbide inserts. From results, it was found that application of the nanographene-enhanced vegetable oil fluid reduced the tool wear and edge chipping. Roy and Ghosh [59] reported a 1030\% reduction in tool-tip temperature using MQL as compared to flood cooling during turning of AISI 4140 steel. Further, better heat-absorbing characteristics were reported using Nanofluid MQL lubrication as compared to conventional MQL. Najiha et al. [60] inspected the effect of water-based $\mathrm{TiO}_{2}$ Nano fluid-based $\mathrm{MQL}$ during end milling of aluminium alloy AA606. Nanoparticle concentration of 2.5\% gave better results in terms of tool performance. Minh et al.[61]did hard milling of hardened steel using $\mathrm{Al}_{2} \mathrm{O}_{3}$ nanoparticle with soybean oil-based MQL and pure MQL conditions. The comparative analysis showed that using nanoparticles based MQL $0.5 \mathrm{wt} \%$ of $\mathrm{Al}_{2} \mathrm{O}_{3}$, tool life increased by $177 \%$ in comparison to pure MQL, with reduction of cutting forces. Singh et al. [62] performed face milling of Inconel 625 under nanoparticles based MQL conditions using different weight concentrations of multi-walled carbon nanotubes (MWCNT) in lubricant and pure MQL environment. The results as shown in figure11 reported that nanoparticles based MQL conditions with $1 \%$ weight concentration of MWCNT have given the best results in terms of tool performance. Tool wear under NMQL reduced by $11.18 \%$ as compared to pure MQL conditions.

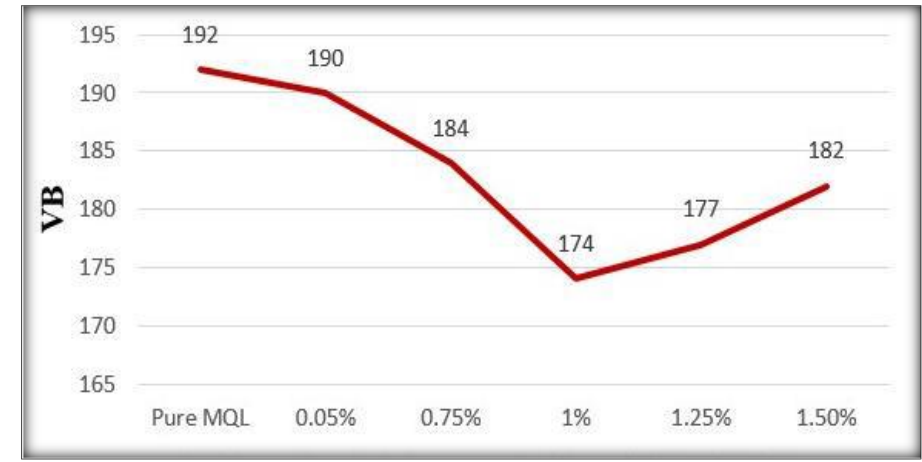

Figure 11: Effect of Different wt. \% of MWCNTs on Tool Wear (VB) [62]. 
Table 2: Summary of the Effects of the Nanoparticle-based MQL Technique on Tool Performances

\begin{tabular}{|c|c|c|c|c|c|}
\hline Authors & Cutting Tool & $\begin{array}{c}\text { Workpiece } \\
\text { material } \\
\end{array}$ & Nanoparticle & Base fluid & Findings \\
\hline $\begin{array}{l}\text { Amrita et } \\
\text { al. [54] }\end{array}$ & $\begin{array}{l}\text { Carbide tool } \\
\text { insert }\end{array}$ & $\begin{array}{l}\text { AISI-1040 } \\
\text { steel }\end{array}$ & Nano-graphite & $\begin{array}{l}\text { water- } \\
\text { soluble oil }\end{array}$ & $\begin{array}{l}\text { Nanofluid in MQL lowered the } \\
\text { machining temperature, tool wear } \\
\text { with better surface qualities }\end{array}$ \\
\hline $\begin{array}{l}\text { Thakur et } \\
\text { al. [55] }\end{array}$ & $\begin{array}{l}\text { Coated tungsten } \\
\text { carbide insert }\end{array}$ & $\begin{array}{l}\text { EN-24 Steel } \\
\text { (AISI } 4340 \\
\text { steel) }\end{array}$ & $\mathrm{SiC}$ & $\begin{array}{l}\text { water- } \\
\text { soluble oil }\end{array}$ & $\begin{array}{l}\text { SiCNanofluids Based Minimum } \\
\text { Quantity Lubrication reported } \\
\text { less surface roughness, cutting } \\
\text { force and cutting temperature }\end{array}$ \\
\hline $\begin{array}{l}\text { Yıldırım } \\
\text { et al. [56] }\end{array}$ & $\begin{array}{l}\text { PVD TiAlN- } \\
\text { TiN coated } \\
\text { cemented } \\
\text { carbide insert }\end{array}$ & Inconel 625 & hBN nanoparticles & $\begin{array}{l}\text { Plantocut } \\
10 \mathrm{SR}\end{array}$ & $\begin{array}{l}\text { The reduction of } 43 \% \text { in tool } \\
\text { wear was recorded using } 0.5 \\
\text { vol } \% \text { hBNnano-fluid }\end{array}$ \\
\hline $\begin{array}{l}\text { Sharma et } \\
\text { al.[57] }\end{array}$ & $\begin{array}{l}\text { Uncoated } \\
\text { cemented } \\
\text { carbide insert }\end{array}$ & $\begin{array}{l}\text { AISI } 1040 \\
\text { steel }\end{array}$ & $\mathrm{SiO}_{2}$ & $\begin{array}{l}\text { Vegetable } \\
\text { oil }\end{array}$ & $\begin{array}{l}\text { Application of } \mathrm{SiO}_{2} \text { based-Nano } \\
\text { fluid lowered the tool wear as } \\
\text { compared to other cooling } \\
\text { systems }\end{array}$ \\
\hline $\begin{array}{l}\text { Park et al. } \\
{[58]}\end{array}$ & $\begin{array}{l}\text { TiAlN coated } \\
\text { carbide } \\
\text { inserts }\end{array}$ & $\begin{array}{l}\text { AISI } 1045 \\
\text { steel }\end{array}$ & $\begin{array}{l}\text { Exfoliated } \\
\text { graphite Nano- } \\
\text { platelets (xGnP) }\end{array}$ & $\begin{array}{l}\text { Vegetable } \\
\text { oil }\end{array}$ & $\begin{array}{l}\text { NMQL reduced the chipping at } \\
\text { the cutting edge and central wear }\end{array}$ \\
\hline $\begin{array}{l}\text { Roy and } \\
\text { Ghosh } \\
{[59]}\end{array}$ & $\begin{array}{l}\text { multi-layered } \\
\text { coated } \\
\text { carbide insert }\end{array}$ & $\begin{array}{l}\text { AISI } 4140 \\
\text { steel }\end{array}$ & $\begin{array}{l}\text { multi-walled } \\
\text { carbon nanotubes }\end{array}$ & $\begin{array}{l}\text { water- } \\
\text { soluble oil }\end{array}$ & $\begin{array}{l}\text { better heat-absorbing } \\
\text { characteristics were reported } \\
\text { using Nanofluid MQL lubrication } \\
\text { as compared to conventional } \\
\text { MQL }\end{array}$ \\
\hline $\begin{array}{l}\text { Najiha et } \\
\text { al.[60] }\end{array}$ & $\begin{array}{l}\text { Tungsten } \\
\text { Carbide-Cobalt } \\
\text { inserts }\end{array}$ & $\begin{array}{l}\text { aluminium } \\
\text { alloy AA6061 }\end{array}$ & $\mathrm{TiO} 2$ & $\begin{array}{l}\text { de-ionized } \\
\text { water }\end{array}$ & $\begin{array}{l}\text { nanoparticle with } 2.5 \% \\
\text { concentration gave better results } \\
\text { in terms of tool damage }\end{array}$ \\
\hline $\begin{array}{l}\text { Minh et } \\
\text { al. [61] }\end{array}$ & $\begin{array}{l}\text { cemented } \\
\text { carbide tools }\end{array}$ & $\begin{array}{l}\text { hardened } \\
60 \mathrm{Si} 2 \mathrm{Mn} \text { steel }\end{array}$ & $\mathrm{Al}_{2} \mathrm{O}$ & $\begin{array}{l}\text { soybean } \\
\text { oil }\end{array}$ & $\begin{array}{l}\text { tool life increased by } 177 \% \text { using } \\
\text { NMQL in comparison to pure } \\
\text { MQL }\end{array}$ \\
\hline $\begin{array}{l}\text { Singhet al. } \\
{[62]}\end{array}$ & $\begin{array}{l}\text { PVD }(\mathrm{Al} / \mathrm{Ti}) \mathrm{N} \\
\text { coated Carbide } \\
\text { Tool }\end{array}$ & Inconel 625 & $\begin{array}{l}\text { multi-walled } \\
\text { carbon nanotubes }\end{array}$ & $\begin{array}{l}\text { Soybean } \\
\text { oil }\end{array}$ & $\begin{array}{l}\text { Under NMQLTool wear by } \\
11.18 \% \text { with } 17.73 \% \text { better } \\
\text { surface finish as compared to } \\
\text { pure MQL conditions. }\end{array}$ \\
\hline
\end{tabular}

\section{CONCLUSIONS}

Many researchers have reported a comparative analysis of various machining environments in different machining processes. MQL has grabbed the attention of researchers in the field of machining and they compared the performance of MQL with other cooling techniques in different machining operations like turning, milling, drilling, etc. MQL can be used as a good alternative especially for high-speed machining or in the machining of hard materials. Following conclusions drawn from this study.

- It was observed by many researchers that better lubrication and penetration was obtained in MQL condition than dry machining and flood cooling. It reduces the cutting zone temperature, cutting forces and thus reduces the tool wear.

- Researchers have reported the behaviour of various cutting tools and their wear mechanism in different machining operations. Tool wear analysis done by many researchers shows that the wear was mainly caused by adhesion and abrasion or the combination of both.

- Formation of a protective oxide layer at the tool chip interface was observed by many researchers under MQL 
environment which results in better cooling at the machining zone.

- Many researchers varied the MQL parameters like Nozzle position, lubricant flow rate and air pressure etc. Optimized value of these parameters reported superior results in terms of tool life, surface qualities and other output characteristics.

- Experimental results of many researchers have shown that the effectiveness of MQL system can be increased by addingnanofluid particles in conventional lubricant.

- Better surface qualities were obtained under MQL conditions due to better heat dissipation and lubricating effect.

\section{REFERENCES}

1. Kumar, R., Pradhan, M. K. and Kumar, R., 2014. Modeling and Optimization of Milling Parameters on Al-6061 Alloy Using Multi- Objective Genetic Algorithm', Design and Research Conference (AIMTDR 2014), 89, 1-7.

2. Singh, R. Introduction to basic manufacturing processes and workshop technology, (2006). New Age International Pvt. Ltd.

3. Warghat, S.T. and Deshmukh, T.R., 2015. A review on optimization of machining parameters for end milling operation', International Journal of Engineering and Applied Research, 315, 31-35.

4. Nabhani, F., 2001. Wear mechanisms of ultra-hard cutting tools materials', Journal of Materials Processing Technology, 115(3), 402-412.

5. Nouri, M., Fussell, B.K., Ziniti, B.L. and Linder, E., 2015. Real-time tool wear monitoring in milling using a cutting condition independent method', International Journal of Machine Tools and Manufacture, 89, 1-13.

6. Sun, J., Wong, Y.S., Rahman, M., Wang, Z.G., Neo, K.S., Tan, C.H. and Onozuka, H., 2006. Effects of coolant supply methods and cutting conditions on tool life in end milling titanium alloy', Machining Science and Technology, 10(3), 355-370.

7. Brinksmeier, E., Walter, A., Janssen, R. and Diersen, P., 1999. Aspects of cooling lubrication reduction in machining advanced materials', Proceedings of the Institution of Mechanical Engineers, Part B: Journal of Engineering Manufacture, 213(8), 769778.

8. Weinert, K., Inasaki, I., Sutherland, J.W. and Wakabayashi, T., 2004. Dry machining and minimum quantity lubrication', CIRP Annals-Manufacturing Technology, 53(2), 511-537.

9. Masood, I., Jahanzaib, M. and Haider, A., 2016. Tool wear and cost evaluation of face milling grade 5 titanium alloy for sustainable machining', Advances in Production Engineering \& Management, 11(3), 239-242.

10. Kurniawan, D.,Yusof, N. M., Sharif, S.,2010. Hard machining of stainless steel using wiper coated carbide: Tool life and surface integrity, Materials and Manufacturing Processes, 25, 370-377, (2010)

11. Ravindra, K.,Palakudtewar, Sharad, V., Gaikwad, 2012. Dry Machining of Superalloys: Difficulties and Remedies, International Journal of Science and Research, Impact factor:3.358

12. Sun, S., Brandt, M., Dargusch, M. S., 2015. Effect of tool wear on chip formation during dry machining of Ti-6Al-4V alloy, part 2: Effect of tool failure modes. Journal of engineering manufacture,

13. Sreejith, P.S. and Ngoi, B.K.A., 2000. Dry machining: machining of the future', Journal of Materials Processing Technology, 101(1-3), 287-291.

14. Su, Y., He, N., Li, L. and Li, X.L., 2006. An experimental investigation of the effects of cooling/lubrication conditions on tool wear in high-speed end milling of Ti-6Al-4V', Wear, 261(7-8), 760-766. 
15. Shashidhara, Y. M., Jayaram, S. R., 2010. Vegetable oils as a potential cutting fluid-an evolution, Tribology International, 43, 1073-1081

16. Shokrani, A., Dhokia, V., Newman, S. T., 2012. Environmentally conscious machining of difficult-to-machine materials with regards to cutting fluids, International Journal of Machine Tools \& Manufacture, 57, 83-101

17. Roy, S., Chand, S., Kumar, R. and Das, R.K., 2019. A Brief Review on Machining Operations Conducted Using Different Machining Inserts Under Minimum Quantity Lubrication Environment. Materials Today: Proceedings, 18, pp.3134-3143.

18. Schwarz, M., Dado, M., Hnilica, R. and Veverková, D., 2015. Environmental and health aspects of metalworking fluid use', Polish Journal of Environmental Studies, 24(1).

19. Suuronen, K., Aalto-Korte, K., Piipari, R., Tuomi, T. and Jolanki, R., 2007. Occupational dermatitis and allergic respiratory diseases in Finnish metalworking machinists', Occupational Medicine, 57(4), 277-283.

20. Meza, F., Chen, L. and Hudson, N., 2013. Investigation of respiratory and dermal symptoms associated with metal working fluids at an aircraft engine manufacturing facility', American journal of industrial medicine, 56(12), 1394-1401.

21. Wu, C.H. and Chien, C.H., 2007. Influence of lubrication type and process conditions on milling performance', Proceedings of the Institution of Mechanical Engineers, Part B: Journal of Engineering Manufacture, 221(5), 835-843.

22. Klocke, F., Eisenblatter, G., 1997. Dry cutting', CIRP Ann. 46, 519-526.

23. Jamadar, A.A., Awale V.S. and Kale, M.S. 2017. Minimum Quantity Lubrication', International Journal of Advanced Research in Science, Engineering and Technology, 4(1)., 3150-3156.

24. Dhar, N.R., Kamruzzaman, M. and Ahmed, M., 2006. Effect of minimum quantity lubrication (MQL) on tool wear and surface roughness in turning AISI-4340 steel', Journal of Materials Processing Technology, 172(2), 299-304.

25. Kamata, Y. and Obikawa, T., 2007. High speed MQL finish-turning of Inconel 718 with different coated tools', Journal of Materials Processing Technology, 192, 281-286.

26. Khan, M.M.A., Mithu, M.A.H. and Dhar, N.R., 2009. Effects of minimum quantity lubrication on turning AISI 9310 alloy steel using vegetable oil-based cutting fluid. Journal of materials processing Technology, 209(15-16), 5573-5583.

27. Saini, A., Dhiman, S., Sharma, R. and Setia, S., 2014. Experimental estimation and optimization of process parameters under minimum quantity lubrication and dry turning of AISI-4340 with different carbide inserts. Journal of mechanical science and Technology, 28(6), pp.2307-2318.

28. Chinchanikar, S. and Choudhury, S.K., 2014. Hard turning using HiPIMS-coated carbide tools: Wear behavior under dry and minimum quantity lubrication (MQL). Measurement, 55, pp.536-548.

29. Sharma, J. and Sidhu, B.S., 2014. Investigation of effects of dry and near dry machining on AISI D2 steel using vegetable oil. Journal of cleaner production, 66, pp.619-623.

30. Sarlkaya, M. and Güllü, A., 2015. Multi-response optimization of minimum quantity lubrication parameters using Taguchi-based grey relational analysis in turning of difficult-to-cut alloy Haynes 25. Journal of Cleaner Production, 91, pp.347-357.

31. Rahim, E.A., Ibrahim, M.R., Rahim, A.A., Aziz, S. and Mohid, Z., 2015. Experimental investigation of minimum quantity lubrication (MQL) as a sustainable cooling technique, Procedia CIRP, 26, 351-354.

32. Mia, M., Dey, P.R., Hossain, M.S., Arafat, M.T., Asaduzzaman, M., Ullah, M.S. and Zobaer, S.T., 2018. 'Taguchi S/N based optimization of machining parameters for surface roughness, tool wear and material removal rate in hard turning under MQL cutting condition, Measurement, 122, 380-391. 
33. Rahman, M., Kumar, A.S. and Salam, M.U., 2002. Experimental evaluation on the effect of minimal quantities of lubricant in milling, International Journal of Machine Tools and Manufacture, 42(5), 539-547.

34. Kishawy, H.A., Dumitrescu, M., Ng, E.G. and Elbestawi, M.A., 2005. Effect of coolant strategy on tool performance, chip morphology and surface quality during high-speed machining of A356 aluminum alloy, International Journal of Machine Tools and Manufacture, 45(2), 219-227.

35. Lacalle, L.L., Angulo, C., Lamikiz, A. and Sanchez, J.A., 2006. Experimental and numerical investigation of the effect of spray cutting fluids in high speed milling, Journal of Materials Processing Technology, 172(1), 11-15.

36. Liao, Y.S. and Lin, H.M., 2007. Mechanism of minimum quantity lubrication in high-speed milling of hardened steel, International Journal of Machine Tools and Manufacture, 47(11), 1660-1666.

37. Liew, W.Y.H., 2010. Low-speed milling of stainless steel with TiAlN single-layer and TiAlN/AlCrNnano-multilayer coated carbide tools under different lubrication conditions. Wear, 269(7-8), pp.617-631.

38. Kang, M.C., Kim, K.H., Shin, S.H., Jang, S.H., Park, J.H. and Kim, C., 2008. Effect of the minimum quantity lubrication in highspeed end-milling of AISI D2 cold-worked die steel (62 HRC) by coated carbide tools, Surface and Coatings Technology, 202(2223), $5621-5624$.

39. Sales, W., Becker, M., Barcellos, C.S., Landre Jr, J., Bonney, J. and Ezugwu, E.O., 2009. Tribological behaviour when face milling AISI 4140 steel with minimum quantity fluid application, Industrial Lubrication and Tribology, 61(2), 84-90.

40. Liu, Z.Q., Cai, X.J., Chen, M. and An, Q.L., 2011. Investigation of cutting force and temperature of end-milling Ti-6Al-4V with different minimum quantity lubrication $(M Q L)$ parameters, Proceedings of the Institution of Mechanical Engineers, Part B: Journal of Engineering Manufacture, 225(8), 1273-1279.

41. Cai, X.J., Liu, Z.Q., Chen, M. and An, Q.L., 2012. An experimental investigation on effects of minimum quantity lubrication oil supply rate in high-speed end milling of Ti-6Al-4V, Proceedings of the Institution of Mechanical Engineers, Part B: Journal of Engineering Manufacture, 226(11), 1784-1792.

42. Yan, L., Yuan, S. and Liu, Q., 2012. Influence of minimum quantity lubrication parameters on tool wear and surface roughness in milling of forged steel, Chinese Journal of Mechanical Engineering, 25(3), 419-429.

43. Zhang, S., Li, J.F. and Wang, Y.W., 2012. Tool life and cutting forces in end milling Inconel 718 under dry and minimum quantity cooling lubrication cutting conditions, Journal of Cleaner Production, 32, 81-87.

44. Wang, C.D., Chen, M., An, Q.L., Wang, M. and Zhu, Y.H., 2014. Tool wear performance in face milling Inconel 182 using minimum quantity lubrication with different nozzle positions, International Journal of Precision Engineering and Manufacturing, 15(3), 557-565.

45. Al Bashir, M., Mia, M. and Dhar, N.R., 2018. Investigations on surface milling of hardened AISI 4140 steel with pulse jet MQL applicator. Journal of the Institution of Engineers (India): Series C, 99(3), pp.301-314

46. Werda, S., Duchosal, A., Le Quilliec, G., Morandeau, A. and Leroy, R., 2017. Minimum quantity lubrication advantages when applied to insert flank face in milling, The International Journal of Advanced Manufacturing Technology, 92(5-8), $2391-2399$.

47. Singh, S., Singh, P., Singh, T., Dureja, J., Dogra, M. And Singh, H., 2017. Minimum Quantity Lubrication (MQL) Milling of Stainless Steel 304 Using Coated Carbide Tool Inserts, IJAMR 9(1), 61-66.

48. Babu, M.N., Anandan, V., Muthukrishnan, N. and Santhanakumar, M., 2019. End milling of AISI 304 steel using Minimum Quantity Lubrication. Measurement, 138, pp.681-689.

49. Singh, G., Gupta, M.K., Mia, M. and Sharma, V.S., 2018. Modeling and optimization of tool wear in MQL-assisted milling of 
Inconel 718 superalloy using evolutionary techniques. The International Journal of Advanced Manufacturing Technology, 97(14), pp.481-494

50. Heinemann, R., Hinduja, S., Barrow, G. and Petuelli, G., 2006. Effect of MQL on the tool life of small twist drills in deep-hole drilling, International Journal of Machine Tools and Manufacture, 46(1), 1-6.

51. Meena, A., Mansori, M.E., 2011. Study of dry and minimum quantity lubrication drilling of novel austempered ductile iron (ADI) for automotive applications. Wear 271, 2412-2416.

52. Bhowmick, S. and Alpas, A.T., 2011. The role of diamond-like carbon coated drills on minimum quantity lubrication drilling of magnesium alloys. Surface and Coatings Technology, 205(23-24), pp.5302-5311.

53. Sharma, A.K., Tiwari, A.K., Dixit, A.R., 2015a. Progress of nanofluid application inmachining: a review. Mater. Manuf. Process. $30(7), 813 e 828$.

54. Amrita, M., Srikant, R.R. and Sitaramaraju, A.V., 2014. Performance evaluation of nanographite-based cutting fluid in machining process. Materials and Manufacturing Processes, 29(5), pp.600-605.

55. Thakur, A., Manna, A. and Samir, S., 2020. Multi-Response Optimization of Turning Parameters during Machining of EN-24 Steel with SiCNanofluids Based Minimum Quantity Lubrication. Silicon, 12(1), pp.71-85.

56. Yıldırım, C..V., Sarıaya, M., Kıvak, T. and Şirin, Ş., 2019. The effect of addition of hBN nanoparticles to nanofluid-MQL on tool wear patterns, tool life, roughness and temperature in turning of Ni-based Inconel 625. Tribology International, 134, pp.443456.

57. Sharma, A.K., Tiwari, A.K., Dixit, A.R. and Singh, R.K., 2017. Investigation into performance of SiO2 nanoparticle-based cutting fluid in the machining process. Materials Today: Proceedings, 4(2), pp.133-141Park

58. Park, K.H., Ewald, B. and Kwon, P.Y., 2011. Effect of nano-enhanced lubricant in minimum quantity lubrication balling milling. Journal of tribology, 133(3).

59. Najiha, M.S., Rahman, M.M. and Kadirgama, K., 2016. Performance of water-based TiO2 nanofluid during the minimum quantity lubrication machining of aluminium alloy, AA6061-T6. Journal of cleaner production, 135, pp.1623-1636.

60. Minh D. T., The L. T., Bao N. T.,2017. Performance of Al2O3 nanofluids in minimum quantity lubrication in hard milling of 60Si2Mn steel using cemented carbide tools. Advances in Mechanical Engineering, 9(7).

61. Kursuncu, B. and Yaras, A.,2018. Assessment of the effect of borax and boric acid additives in cutting fluids on milling of AISI O2 using MQL system. The International Journal of Advanced Manufacturing Technology, 95(5-8): 2005-2013.

62. Singh, P., Dureja, J.S., Singh, H. and Bhatti, M.S., 2019. Nanofluid-based Minimum Quantity Lubrication (MQL) Face Milling of Inconel 625. International Journal of Automotive and Mechanical Engineering, 16(3), pp.6874-6888 